\title{
NEWS ON THE BATTLE OF PETROVARADIN AND THE SIEGE OF BELGRADE IN THE AUTOBIOGRAPHICAL WRITINGS OF JEAN-FRÉDÉRIC DIESBACH ${ }^{2}$
}

\begin{abstract}
This paper is based on data from the handwritten autobiography of JeanFrédéric Diesbach, which is kept in the Historical Archives in Fribourg, Switzerland, and in which the Battle of Petrovaradin and the siege of Belgrade are discussed. Diesbach, a Swiss nobleman who was originally in the Swiss and French military service, was later transferred to the Austrian army. This well-known European military leader finished his career as a governor of Syracuse in Sicily and a Major General of the Austrian army. A segment of his memories provides a brief description of the Battle of Petrovaradin and the operations of the Austrian army during the siege of Belgrade. Although it is part of the manuscript of a few pages, it has the value of a historical source, because it is the testimony of participants in these events.
\end{abstract}

KEY WORDS: Battle of Petrovaradin, siege of Belgrade, the Austro-Turkish war, JeanFrédéric Diesbach.

\footnotetext{
dalibor.elezovic@pr.ac.rs

2 The paper presents the results of research conducted under the Project No. III 47023 Kosovo and Metohija between national identity and European integration, which is funded by the Ministry of Education, Science and Technological Development of the Republic of Serbia.

This paper was submitted on August 11, 2016 and accepted for publication at the meeting of the Editorial Board held on 29 September 2016.
} 
Three centuries have passed since the Austrian army, on August 5, 1716, led by Prince Eugene of Savoy, defeated the Ottoman army at the Battle of Petrovaradin. It was heard far and wide about this victory of the Christian army; the western world celebrated it as a great event, and the main actor, Prince Eugene of Savoy was celebrated as Caesar. The news on the battle and the Turkish defeat had long spread; eleven days after the Battle, General Lefelholz wrote to Prince Eugene of Savoy about the problem of burying thousands of Turks who were killed in Petrovaradin (Gavrilović, 2004, p. 147-148). A Turkish official from Belgrade wrote a letter on the eve of the siege of the town, in which, regarding the battle of Petrovaradin, he said that it "[...] has been the bloodiest that he and his men could remember" (Popović, 1974, p. 205). In historiography, the Battle of Petrovaradin has remained in the shadow of the conquest of Belgrade that happened in the following year, the most famous victory of Prince Eugene of Savoy against the Turks (Bešlin, 2014, p. 486; Hantsch, 1994, p. 104-105).

Nowadays any novel news on these historical events, any new fragment of historical circumstances that preceded the battle and sheds light on the events after it, is valuable. The objective of this paper is to contribute to the enlightenment of these events, but also to celebrate the jubilee of the famed battle. As a source, we have used the handwritten autobiography of Jean-Frédéric Diesbach, a copy of which is kept at the State Archives of Fribourg in Switzerland. This historical source provides data on the period from the author's early childhood to the Battle of Parma on June 29, 1734, where he was wounded and then ended his military career (CH AEF, 60a-k). Count Diesbach was an offspring of a well-known aristocratic lineage, originating from Bern, whose one branch moved to Fribourg, and he was one of its major representatives. He began his military career in his homeland, and was later transferred to the French army, in whose ranks he participated in the War of the Spanish Succession (1701-1714). He entered the Austrian military service in 1714, and encyclopedic references state that he stood out in the Austro-Turkish War of 1716-1718 in Petrovaradin, Timisoara, and Belgrade, as well as in the War of the Polish Succession (1733-1738). He later took part in the Austrian army as one of the commanders at the Battle of Parma. His heroism and loyalty was appreciated by Emperor Charles VI (1711-1740), who appointed him the governor of Syracuse in Sicily in 1722 (Ghellinck Vaernewyck 1921, p. 459-463). Diesbach's engagement recognizes 
the practice of Western states in the early modern history, which gave the nobility functions in the civil administration and in the army in accordance with the noble rank (Dilmen, 2010, p. 130).

Diesbach's autobiographical writings are a source of European history of the first three and a half decades of the 18th century. We will try to look at the credibility of this source in terms of authorship and reliability, that is, to answer the question of whether the author was in a position to have information that he put into the text. These are basic questions raised in the analysis of the source and in determining its importance for the historical reconstruction. By a careful analysis of the manuscript, we have come to the conclusion that it is important as a historical source, but also as a specific genre of the older European autobiographical form. In the context of historical sources, Vocelka (2010) supports the approach (in the study of the early modern history) that does not separate autobiographies and diaries as fundamentally different types of sources, but researches them together as social and historical questions. Some of the leading researchers of the period define this group of sources as "personal testimony" (p. 62). Tosh (2009) is of the opinion that autobiographies are infamous due to errors in memory and search for excuses. However, the greatest value lies in their subjectivity, because the pattern that the author applies to his own life is simultaneously both a cultural and personal structure, it sheds light on the conditions under which they were written and in which somebody lived (p. 129). Diesbach's manuscript, in terms of genre, is at the crossroads of memoirs and autobiographies, and archivists have defined it as autobiographical writings. It is a short writing, in French and German, which the author wrote in his later years. The part in German (that we did not use in the paper) was supplemented by historian Max Diesbach in the 19th century. It refers to the most important events of his career and life, which left him with the strongest impression. Therefore, these autobiographical writings look discontinuous, incomplete, and sometimes interrupted when the reader expects the story of an event to be ended. The part that has been the subject of our analysis does not provide any information on specific social issues or information on deeper social issues. In it, there are no data that are controversial in relation to the histories that discuss these events, hence there was no need for a more profound application of the comparative method. By analyzing, we have concluded that the author wrote the memories that left a profound mark on him. Therefore, we feel 
that the belief of well-known anthropologist Bloch (1995), who rightly concludes that autobiographical writings are based on those events that the author has experienced and that have remained etched in his subconscious and memory, is justified. He believes that, to understand these sources in history and sociology, it is important to include psychology, since psychologists emphasize the contrast between memorize and evoke (p. 60-62).

Diesbach begins his testimony with a story about his homeland, the Swiss cantons, which were in special allied relations with France and, through the so-called foreign military service, participated with significant military units in all the wars that this state led throughout several centuries. This tradition of good bilateral relations was maintained until the time of Louis XIV (1643-1715), who, before his death, signed an alliance (Elezović, 2010, p. 234). As a renowned officer, Count Diesbach, on the eve of the Austro-Turkish War, was in the French military service, as the head of a major military unit recruited of soldiers of the Confederacy. He came out of the War of the Spanish Succession, and after the crisis at the end of the reign of Louis XIV, he was demobilized, which he regretted and wrote that this happened despite "[...] so many years spent in the service." It is clear that Diesbach did not willingly leave the French military service as a professional soldier and a man who cared about the traditional relations of the Swiss and the French state. He wrote that he could not provide funds from the French government, needed to pay to the soldiers from his unit, so he was forced to return to Fribourg. For this course of development, he blamed Charles-François de Vintimille du Luc, ${ }^{3}$ the French ambassador to Switzerland, who made the Franco-Swiss relations complicated, as well as the situation of the Swiss units in France. He concludes that du Luc "[...] unfortunately, did not learn anything in Vienna, where he was appointed ambassador at the discretion of the pious King" Louis XIV (CH AEF, 60a-k). Diesbach's story refers to the historical events that resulted in exacerbated relations in the Swiss cantons between the Catholics and the Protestants, but also poorer relations between the Confederation and France. The main actor was the controversial ambassador du Luc, who, during the signing of the treaty in Baden on September 7, 1714, sought to provide favoring of the Catholics in the Confederacy (Schluchter, 2003; Reinhardt, 2011, p. 252-253). Diesbach found himself in his

3 Charles-François de Vintimille du Luc (1653-1740), French ambassador to the Confederacy (Solothurn), and then in Vienna (Schluchter, 2005). 
hometown during the new events on the European political scene. The Ottoman-Venetian War (1714-1718) blurred the then fragile European political scene. Porte accused Venice that, in the subsequent Russo-Turkish conflict, it had provided the Montenegrin fighters with weapons and that it provided refuge for the hajduk soldieries in the southern Adriatic towns (Bešlin, 2014, p. 473). Austria took the side of the Republic of St. Mark, and soon after, entered into a military alliance with it. The year of 1714 passed in preparations of the Austrian army for the upcoming military operations, therefore, it welcomed the experienced warrior Diesbach, who joined the Austrian military service in that year and was promoted to the rank of Major General. In his memoirs, he wrote that, in the Battle of Petrovaradin, he was in the service of "His Majesty" Prince Charles Alexander of Württemberg. ${ }^{4} \mathrm{He}$ also mentioned the death of Field Marshal Breuner, ${ }^{5}$ who was brutally executed during the battle. He presented the fact that, after this event, when the end of the battle was in sight, they captured two Turkish artillery batteries in Petrovaradin forests, "[...] three times stronger than the Austrian" (CH AEF, 60a-k).

The following year, the Austrian army began fortifying their positions in the direction from Petrovaradin along the Danube to Belgrade. Diesbach wrote that those fortifying operations lasted between twelve and fifteen days. The entire operation was made difficult by wetlands and "[...] turbid rivers, whose stagnant water was not useful for the army." We have read in the manuscript that the mentioned direction contained very little forestland, lacked the necessary timber to build carts that transported the board, and they were running out of drinking water ( $\mathrm{CH}$ AEF, 60a-k). These problems were not accidentally engraved on the memory of Count Diesbach, who gave them importance in his testimony, as they were noted in other sources, as well. Bešlin (2014) writes that the Tisa was not a problem for the Austrian army, but the Banat wetlands were. It was difficult for the cannons and carts with the board to move through mud and cross wooden bridges, which were breaking under the burden and had to be repaired from time to time (pp.

4 Charles Alexander of Württemberg (1674-1737), Duke of Württemberg, Field Marshal of the Imperial Army and the Governor of the Kingdom of Serbia from 1720 to 1733 (Wunder, 1977, p. 266).

5 Siegfried Breuner (1670-1716), Count, Austrian field marshal-lieutenant. Captured, brutally tortured, and executed at the Battle of Petrovaradin (Janko, 1876, p. 321). 
488-489). In 1717, Diesbach was a participant in the siege of Belgrade, deployed with six battalions in Banat, and had the task of ensuring a strategic position. Then he joined the other units as "[...] the oldest infantry general" in this operation ( $\mathrm{CH} \mathrm{AEF,} \mathrm{60a-k).} \mathrm{This}$ time, the Austrian army headed to Belgrade from the Banat side along the Danube, which proved to be a good tactic. The previous two times, in 1688 and 1693, they struck from Srem, across the Sava. On the initiative of Count Claude Florimond de Mercy, ${ }^{6}$ Prince Eugene of Savoy decided to strike from Banat (Bešlin, 2014, p. 496-497). As the stages of the siege of Belgrade progressed, the Austrian army kept suppressing the Turkish forces. It is known that, before the battle, the Turks strengthened their forts on the Great War Island, trying to thwart the Austrian ships and flotilla. During the battle, they were pushed back from this position and the Austrian formations were arranged there. From Diesbach's manuscript, we can find out that he was the Commander of the unit on the Great War Island. It was a small formation, whose task was to support the Austrian warships that attacked the Belgrade Fortress ( $\mathrm{CH} \mathrm{AEF,} \mathrm{60a-k).} \mathrm{In} \mathrm{the} \mathrm{literature} \mathrm{referring} \mathrm{this} \mathrm{historic} \mathrm{event,} \mathrm{we}$ were unable to find facts that would disprove these allegations. Therefore, we consider this piece of information, along with a dose of caution, relevant and valuable to illuminate the historical story of the siege of Belgrade.

After great victories at Petrovaradin and Belgrade, the Austrian army transferred the focus of its military operations to Bosnia. Diesbach was sent there the following year and was assigned along the Drina with six military detachments (mainly bombers), four cannons, and a thousand and two hundred horses. This fact affirms that Diesbach had a task to secure part of the board, that is, the horses that were of great importance to the then army. At the time, the Austrian army reached Zvornik and unsuccessfully tried to conquer it, but it remained in the Ottoman hands until the end of the war. The war ended with the Treaty of Požarevac on July 21, 1718 , and Diesbach was ordered to monitor the withdrawal of the Austrian units from Belgrade to Milan, along with the regiments of Durlach $^{7}$ and Braun. In his autobiography, he wrote that, most of

6 Count Claude Florimond de Mercy (1666-1734), Field Marshal of the Austrian Army, the administrator of the imperial province of Banat Timisoara. Charles VI, at the beginning of the War of the Polish Succession, appointed him the commander-in-chief of the imperial army in Italy. He died at the beginning of the Battle of Parma (Neuhaus, 1994, p. 126-127). 
the time from July 20 , to November $1^{\text {st }}$, he spent with the army in Cremona, where he did not suffer major losses (CH AEF, 60a-k). Although today many historians would call him a real "European," since he served and lived from the Netherlands to Spain, and from Sicily to Wallachia, Diesbach missed his homeland because "[...] he had not been in his homeland for a long time." He addressed the Prince of Savoy to allow him to go to Switzerland, and the great military leader granted his wish. Cold and dangerous weather had already begun, but he still started to go over the Alps on November 3, 1718 and, in a few days, arrived in Fribourg, where he stayed until December 23. Then an order came to him to return to Milan, and be at the disposal of Marshal Viscount ${ }^{8}$ who had directed him "[...] through the territory of Parma, Modena and the Papal state to the Kingdom of Naples." In the Italian south, Diesbach ended his career in the operations that were conducted within the War of the Polish Succession ( $\mathrm{CH}$ AEF, 60a-k). At the end, the retired soldier returned to his homeland, where he received a well-deserved respect and the title of an honorary State Counselor. He had the time to note the main sequences from his rich military career, thus leaving behind a valuable source for historiography and other disciplines that study this genre in European culture.

SOURCES The State Archives of Fribourg, Switzerland (CH AEF)

Chronicle Fund, No. 60a-k - Autobiographical Writings of Jean-Frédéric Diesbach (1677-1734).

REFERENCES Бешлин, Б. (2014). Евіеније Савојски и њеїово gоба. Нови Сад: Матица српска.

Bloch, M. (1995). Mémoire autobiographique et mémoire historique du passé éloigné. Enquête (2), 59-76. DOI: 10.4000/enquete.309

Веселиновић, Р. (1986). „Срби под аустријском влашћу 1718-1739”, у С. Гавриловић (ур.), Ист̄орија срӣскої нароga IV-1 (106-162). Београд: Српска књижевна задруга.

7 Charles III William, Margrave of Baden-Durlach (1679-1738), Margrave of Baden, as a senior officer, he participated in the War of the Spanish Succession, a participant in the First (1703) and the Second Battle of Blindheim (1704). He was appointed an imperial field marshal in 1715, and a Swabian general field marshal in 1733. Durlach, at the beginning of the Austro-Turkish war, sent Charles VI his regiment of 2,300 people force. (Kleinschmidt, 1882, p. 237-241).

8 Annibale Visconti (1661-1747), descendant of a noble family Visconti of Milan, appointed an Austrian field marshal in 1716 (Morandotti, 2008, p. 41). 
Vocelka, K. (2010). Geschichte der Neuzeit: 1500-1918. Paderborn: Schöningh.

Wunder, B. (1977), „Karl Alexander” in: F. Wagner (Ed.). Neue Deutsche Biographie 11 (266). Berlin: Ducker und Humbolt.

Гавриловић, С. (2003). Вести о Србији, Босни и Банату уочи и у току

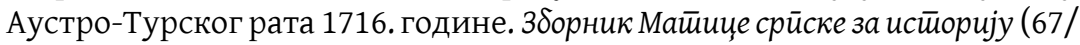
68), 135-150.

Гавриловић, С. (2003). Молба из 1716. становника Срема ради заштите од

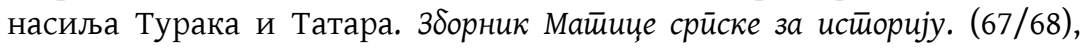
121-124.

Гавриловић, С. (2003). О капетану Теодору Продановићу-Чупићу ("Чупи Капетану"), јунаку и пустахији с почетка XVIII века. $3 \delta о р н и к ~ М а \overline{u и ц е ~}$ срӣске за исйорију (67/68), 51-58.

Гавриловић, С. (1974). Сведочанства о биткама код Ирига и Петроварадина 1716. године. Ист̄оријски часоӣuс (21), 251-254.

Гавриловић, С. (2006). Срби у аустро-турском рату 1716-1718. Гоgишњак Музеја їраgа Нової Caga (2), 83-90.

Грујић, Р. (1935). Белешке о ратовању с Турцима 1716-1717. Гласник

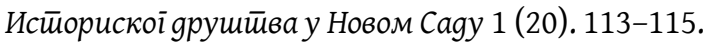

Ghellinck Vaernewyck, A. (1921). La généalogie de la maison de Diesbach. Gand: W. Siffer.

Дилмен, Р. (2010). Исӣорија - Лексикон ӣојмова. Београд: Clio.

Елезовић, Д. (2011). Хроника анонимног аутора о швајцарском најамништву. Прилог историји историографије раног модерног доба.

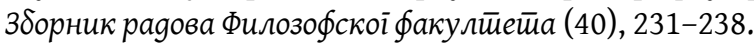

Janko, W. (1876). „Breuner, Siegfried Graf von“ in: R. F. Liliencron (Ed.). Allgemeine Deutsche Biographie 3 (321). Leipzig: Ducker und Humbolt.

Kleinschmidt, A. (1882). „Karl III. Wilhelm“ in: R. F. Liliencron (Ed.). Allgemeine Deutsche Biographie 15 (237-241). Leipzig: Ducker und Humbolt.

Миросављевић, В. (1933). Нови Сад око 1716 године. Гласник Ист̄орискої gрушӣва у Новом Саgy 1-2 (14-15), 193-196.

Morandotti, A. (2008). Il collezionismo in Lombardia. Milano: Officina libraria.

Neuhaus, H. (1994). „Mercy, Claudius Florimund Graf von“ in: H. Jaeger (Ed.). Neue Deutsche Biographie 17 (126-127). Berlin: Ducker und Humbolt.

Поповић, Т. (1991). Један турски извештај о Бици код Петроварадина од

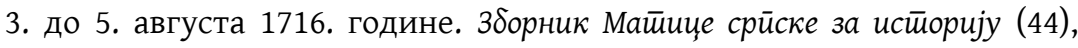
204-205.

Reinhardt, V. (2011). Geschichte der Schweiz. Munchen: C. H. Beck. 
Schluchter, A. (2003). „Du Luc, Charles-François de Vintimille“, Historischen Lexikon der Schweiz. http://www.hls-dhs-dss.ch/textes/d/D28553.php

Тош, Џ., Ланг, Ш. (2008). у ӥраїању за истооријом: изиљеви, мет̄оgи и нови йравици у йроучавању савремене ист̄орије. Београд: Clio, 2008.

Hantsch, H. (1994). Die Geschichte ser Osterreichs. Graz: Styria.

Храбак, Б. (1997). Северозападна Србија у Аустро-турском рату 1716-1718. 3борник раgова Нароgноі музеја (27), 83-127. 


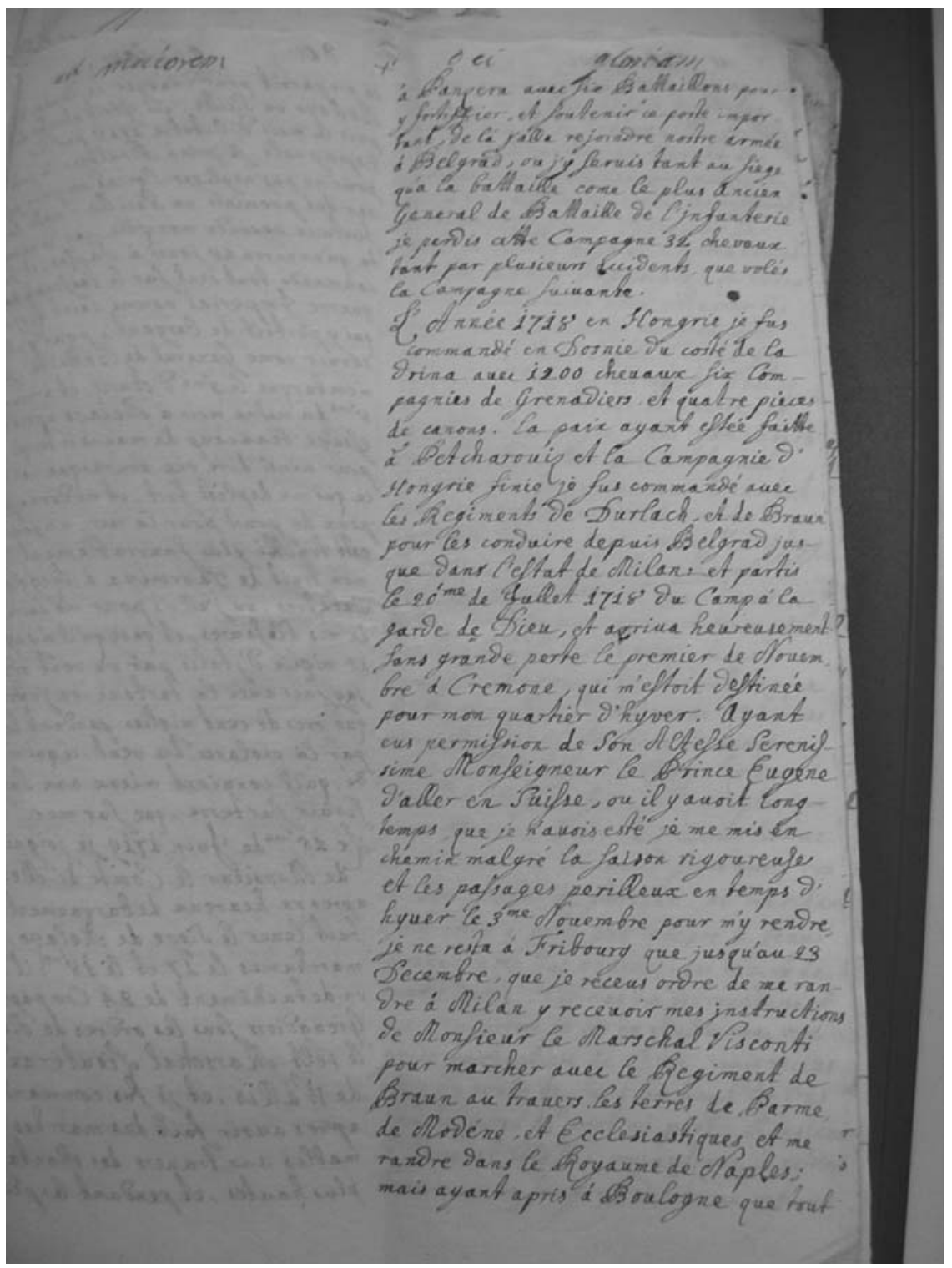

Attachment: Autobiographical Writings of Jean-Frédéric Diesbach (State Archives Fribourg, Switzerland) ${ }^{9}$

9 Photographed by: Dalibor Elezović, March 18, 2011 
ДАЛИБОР М. ЕЛЕЗОВИЋ

УНИВЕРЗИТЕТ У ПРИШТИНИ С ПРИВРЕМЕНИМ СЕДИШТЕМ

У КОСОВСКОЈ МИТРОВИЦИ, ФИЛОЗОФСКИ ФАКУЛТЕТ

КАТЕДРА ЗА ИСТОРИЈУ

РЕЗИМЕ

ВЕСТИ О БИЦИ КОД ПЕТРОВАРАДИНА И ОПСАДИ БЕОГРАДА У АУТОБИОГРАФСКИМ СПИСИМА ЖАНА ФРЕДЕРИКА ДИЗБАХА

Рад се заснива на подацима из рукописне аутобиографије Жана Фредерика Дизбаха, која се чува у Историјском архиву у Фрибургу у Швајцарској и у којој се говори о Бици код Петроварадина и опсади Београда. Дизбах, швајцарски племић који је био првобитно у швајцарској и француској војној служби, касније је прешао у аустријску војску. Овај познати европски војсковођа каријеру је завршио као гувернер Сиракузе на Сицилији и генерал-мајор аустријске војске. Сегмент његових сећања пружа кратак опис битке код Петроварадина и операција аустријске војске током опсаде Београда.

Кључне речи: битка код Петроварадина, опсада Београда, Аустро-турски рат, Jean-Frédéric Diesbach. 